\title{
Biological Degradation of Metribuzin and Profenofos by some Efficient Bacterial Isolates
}

\author{
C. Tamilselvan*, S. John Joseph, G. Mugunthan, A. Sathish Kumar, \\ S. Syed Musthaq Ahamed \\ Bioscience Research Foundation, Porur, Chennai, 600 116, Tamil Nadu, India \\ *E-mail address: brfchennai@gmail.com
}

\begin{abstract}
The soil sample was collected from the paddy field of Sriperumbudur, Tamilnadu which is having a history of repeated pesticide applications. The isolation of efficient pesticide degrading bacteria was identified as Pseudomonas aeruginosa, Staphylococcus aureus and Bacillus subtilis. The growth of the three pesticide degrading isolates was assessed in Minimal salt broth containing $25 \mathrm{ppm}$ of pesticides. Two popularly used pesticides Metribuzin and Profenofos were selected for this study. Among the three bacterial isolates, the bacteria Bacillus subtilis utilized the pesticides effectively and showed maximum growth. The growth of the three pesticides degrading isolates Pseudomonas aeruginosa, Staphylococcus aureus and Bacillus subtilis was assessed in Minimal salt broth containing $25 \mathrm{ppm}$ of pesticides at different temperature levels $\left(25^{\circ} \mathrm{C}, 30^{\circ} \mathrm{C}, 35^{\circ} \mathrm{C}, 40^{\circ} \mathrm{C}, 45^{\circ} \mathrm{C}, 50\right.$ ${ }^{\circ} \mathrm{C} \& 55^{\circ} \mathrm{C}$ ) and $\mathrm{pH}$ levels ( $\left.\mathrm{pH} 4, \mathrm{pH} 5, \mathrm{pH} 6, \mathrm{pH} 7 \& \mathrm{pH} 8\right)$ and carbon sources (Lactose, Dextrose, Fructose, Mannose \& Galactose) and nitrogen sources Peptone, Yeast extract, Beef extract, Malt extract and Casein respectively. The maximum growth rate of bacteria was recorded at $35{ }^{\circ} \mathrm{C}$ and $\mathrm{pH}$ 6. The maximum growth of bacteria was in the presence of Dextrose followed by Fructose, Galactose and Mannose. The least growth was recorded in Lactose broth culture. The maximum growth of bacteria was in the presence of Malt extract followed by Peptone, Yeast extract and Casein. The least growth was recorded in Beef extract broth culture. The bacterial isolates showed maximum growth in the Minimal salt broth containing Profenofos followed by Metribuzin.
\end{abstract}

Keywords: Metribuzin; Profenofos; Pseudomonas aeruginosa; Staphylococcus aureus; Bacillus subtilis

\section{INTRODUCTION}

India is an agriculture based country. About $60-70 \%$ of its population is dependent on agriculture. A major portion of arable land already under cultivation is being rapidly depleted by industries and urban encroachments. On the other hand, the demand for agricultural crops is increasing day by day due to the rapidly increasing population. Hence, there is a need for a huge increase in the quantity and quality of agricultural produce. To meet these objectives; agrochemicals like insecticides, fungicides, pesticides, and herbicides and also; use of better quality seeds are being used on a large scale in agricultural lands. About $30 \%$ of agricultural produce is lost due to pests. 
Hence the use of pesticides becomes indispensable in agriculture [1]. At present more than 250 active substances and approximately 10,000 formulations have been incorporated in India and which are known as pesticides. Insecticides represent the greatest proportion of pesticides used in developing countries, whereas herbicide sales have been greater than those of other pesticides in industrialized countries. Now a day Biopesticides are also great importance in India.

Although some persistence organochlorine pesticides have been banned from agricultural and public health use during the past few decades, high concentrations of pesticides and its metabolites have been found in soil, water, and sediment samples [2-4]. Furthermore, other insecticides, such as endosulfan and lindane, are currently restrict in use throughout the world [5] and their presence in air, water, and soil is a problem of great concern. Microbial degradation of pesticides applied to soil is the principle mechanism which prevents the accumulation of these chemicals in the environment to reducing their levels in the environment has therefore become an important goal.

\section{MATERIALS AND METHODS}

\section{1. Collection of soil sample}

The soil samples were collected from the different places of paddy fields of Sriperumbudur, Tamilnadu which is having a history of repeated pesticide applications. The collected soil samples were ground, passed through $2 \mathrm{~mm}$ sieve and stored at $4{ }^{\circ} \mathrm{C}$.

\section{2. Pesticides used}

Pesticides used in this present study are

a) Profenofos

b) Metribuzin

\section{3. Isolation and identification of bacterial isolates}

Pour plate technique was used for the isolation of efficient pesticide degrading bacteria in Nutrient agar and King,s B agar plate. Well grown bacterial colonies were picked and further purified by streaking method. The isolated strains were maintained on Nutrient agar and King,s B agar slants and stored at $4{ }^{\circ} \mathrm{C}$. Identification of the three different bacterial isolates was carried out by the routine bacteriological methods i.e., By the colony morphology, preliminary tests like Gram staining, Capsule staining, Endospore staining, Motility, Catalase and Oxidase, Plating on selective media and by performing biochemical tests.

\section{4. Determination of the growth of pesticide degrading bacterial isolates on minimal salt broth}

The suspension of 24 hours old cultures of Pseudomonas aeruginosa, Staphylococcus aureus and Bacillus subtilis were used to prepare the bacterial inoculum. They were prepared in saline solution ( $0.85 \%$ sodium chloride). A loopful of Pseudomonas aeruginosa, Staphylococcus aureus and Bacillus subtilis cultures were inoculated into $25 \mathrm{ml}$ of saline and incubated at $37^{\circ} \mathrm{C}$ for 3 hours.

The growth of pesticide degrading bacterial isolates (Pseudomonas aeruginosa, Staphylococcus aureus and Bacillus subtilis) was determined by using Minimal Salt Broth. 
For this, $2 \mathrm{ml}$ of the bacterial inoculum was inoculated into $100 \mathrm{ml}$ of Mineral salt broth containing $25 \mathrm{ppm}$ of two different pesticides. The flasks were then incubated at $37^{\circ} \mathrm{C}$ for 7 days in a microbial shaker at $150 \mathrm{rpm}$. Five $\mathrm{ml}$ of culture was drawn and centrifuged at 5000 rpm for 10 minutes. The pellet was discarded and the supernatant was collected to evaluate the growth of pesticide degrading bacteria. The growth of the pesticide degrading bacterial isolates was assessed by using UV - spectrophotometer at $542 \mathrm{~nm}$.

\section{5. Effect of temperature for the growth of pesticide degrading bacterial isolates}

To study the stability of the bacterial isolates for the biodegradation of pesticides, an experiment conducted in a Erlenmeyer flask containing $25 \mathrm{ppm}$ of pesticides in $100 \mathrm{ml}$ Minimal salt broth. After sterilization by autoclaving the flask were cooled and inoculated with the bacterial cultures and maintained at different temperature $\left(25^{\circ} \mathrm{C}, 30^{\circ} \mathrm{C}, 35^{\circ} \mathrm{C}, 40\right.$ ${ }^{\circ} \mathrm{C}, 45^{\circ} \mathrm{C}, 50{ }^{\circ} \mathrm{C}$ and $55^{\circ} \mathrm{C}$ ). After 24 hours, $10 \mathrm{ml}$ of culture was drawn and centrifuged at $5000 \mathrm{rpm}$ for 10 minutes and the pellet were discarded and the supernatant was collected to evaluate the growth of pesticide degrading bacteria. The optical density was taken at $542 \mathrm{~nm}$ using UV - spectrophotometer.

\section{6. Effect of pH for the growth of pesticide degrading bacterial isolates}

To study the stability of the bacterial isolates for the biodegradation of pesticides, an experiment conducted in a Erlenmeyer flask containing $25 \mathrm{ppm}$ of pesticides in $100 \mathrm{ml}$ Minimal salt broth. After sterilization by autoclaving the flask were cooled and inoculated with the bacterial cultures and maintained at different $\mathrm{pH}(4,5,6,7$ and 8). After 24 hours, 10 $\mathrm{ml}$ of culture was drawn and centrifuged at $5000 \mathrm{rpm}$ for 10 minutes. The pellet was discarded and the supernatant was collected to evaluate the growth of pesticide degrading bacteria and the optical density was taken at $542 \mathrm{~nm}$ using UV - spectrophotometer.

\section{7. Effect of carbon sources for the growth of pesticide degrading bacterial isolates}

The effect of various carbon sources for the maximization of pesticide biodegradation was tested. The bacterial isolates were cultivated in $100 \mathrm{ml}$ of Mineral salt broth with $25 \mathrm{ppm}$ of pesticides and $1 \mathrm{~g}$ of various carbon sources (Lactose, Dextrose, Fructose, Mannose and Galactose) and incubated at $37{ }^{\circ} \mathrm{C}$. After 24 hours, $10 \mathrm{ml}$ of culture was drawn and centrifuged at $5000 \mathrm{rpm}$ for 10 minutes. The pellet was discarded and the supernatant was collected to evaluate the growth of pesticide degrading bacteria and the optical density was taken at $542 \mathrm{~nm}$ using UV - spectrophotometer.

\section{8. Effect of nitrogen sources for the growth of pesticide degrading bacterial isolates}

The effect of various carbon sources for the maximization of pesticide biodegradation was tested. The bacterial isolates were cultivated in $100 \mathrm{ml}$ Minimal salt broth with $25 \mathrm{ppm}$ of pesticides and $1 \mathrm{~g}$ of various nitrogen sources (Peptone, Yeast extract, Beef extract, Malt extract and Casein) and incubated at $37^{\circ} \mathrm{C}$. After 24 hours, $10 \mathrm{ml}$ of culture was drawn and centrifuged at $5000 \mathrm{rpm}$ for 10 minutes. The pellet was discarded and the supernatant was collected to evaluate the growth of pesticide degrading bacteria and the optical density was taken at $542 \mathrm{~nm}$ using UV - spectrophotometer. 


\section{RESULTS AND DISCUSSION}

In this present experiment, the growth of the three pesticide degrading isolates Pseudomonas aeruginosa, Staphylococcus aureus and Bacillus subtilis was assessed in Minimal salt broth containing $25 \mathrm{ppm}$ of pesticides. Two different pesticides Metribuzin and Profenofos were used in this study. Among the three bacterial isolates, the bacteria Bacillus subtilis utilized the pesticides effectively and showed maximum growth (OD value) followed by Staphylococcus aureus and Pseudomonas aeruginosa. The bacterial isolates showed (Table and Fig $1 \&$ 2) maximum growth in the Minimal salt broth containing Profenofos (0.586) followed by Metribuzin (0.462).

Table 1. Growth of pesticide degrading bacterial isolates on Minimal Salt broth containing Metribuzin.

\begin{tabular}{|c|c|c|c|}
\hline Days & $\begin{array}{c}\text { Pseudomonas aeruginosa } \\
\text { (OD at 542 } \mathrm{nm} \text { ) }\end{array}$ & $\begin{array}{c}\text { Staphylococcus aureus } \\
\text { (OD at 542 } \mathrm{nm} \text { ) }\end{array}$ & $\begin{array}{c}\text { Bacillus subtilis } \\
\text { (OD at 542 } \mathrm{nm} \text { ) }\end{array}$ \\
\hline 0 & 0.213 & 0.239 & 0.268 \\
\hline 1 & 0.258 & 0.284 & 0.372 \\
\hline 2 & 0.274 & 0.317 & 0.349 \\
\hline 3 & 0.301 & 0.336 & 0.351 \\
\hline 4 & 0.396 & 0.369 & 0.364 \\
\hline 5 & 0.352 & 0.381 & 0.405 \\
\hline 6 & 0.375 & 0.415 & 0.448 \\
\hline 7 & 0.406 & 0.453 & 0.462 \\
\hline
\end{tabular}

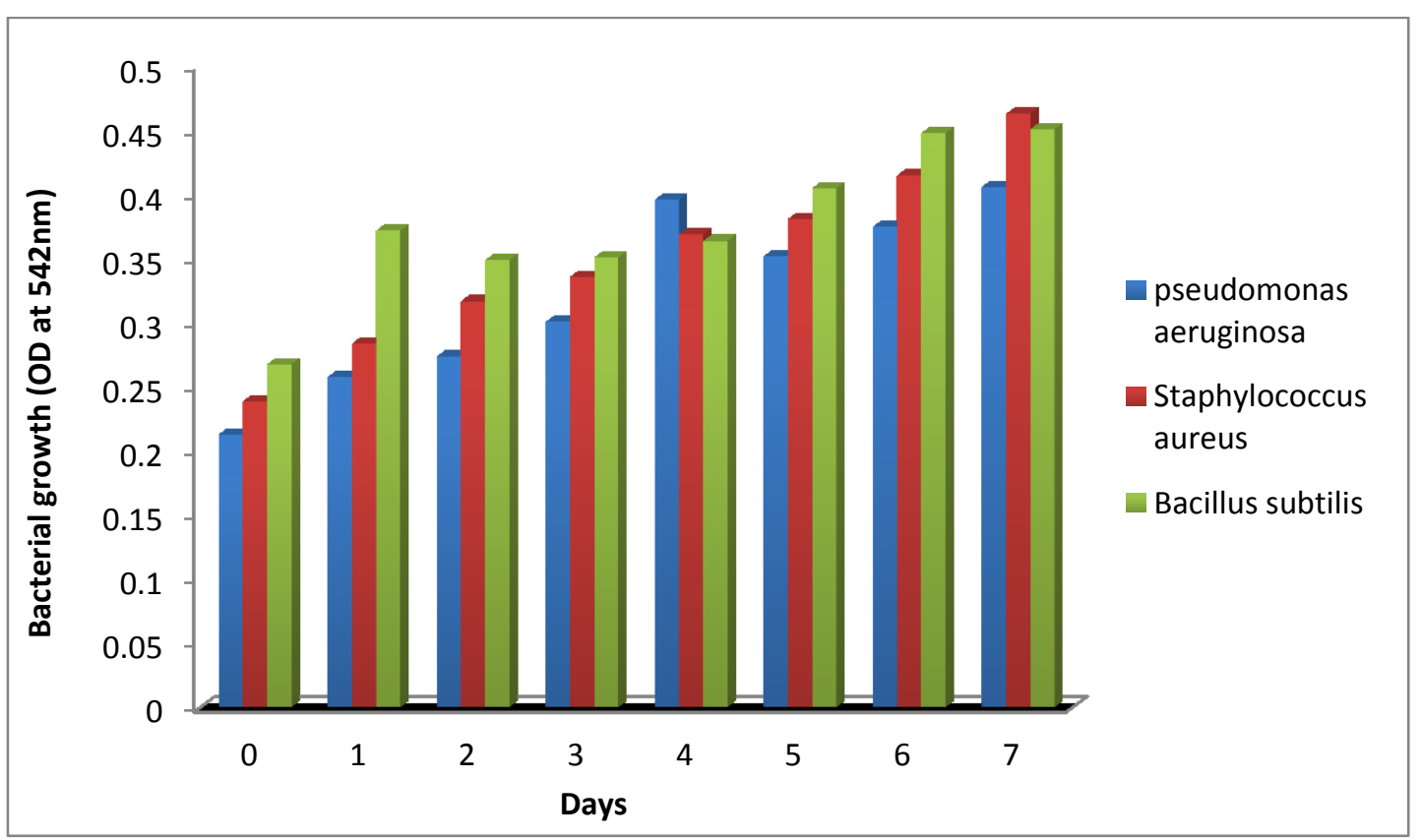

Fig. 1. Clustered column chart of Growth of pesticide degrading bacterial isolates on Minimal Salt broth containing Metribuzin. 
Table 2. Growth of pesticide degrading bacterial isolates on Minimal Salt broth containing Profenofos.

\begin{tabular}{|c|c|c|c|}
\hline Days & $\begin{array}{c}\text { Pseudomonas aeruginosa } \\
\text { (OD at 542 } \mathrm{nm} \text { ) }\end{array}$ & $\begin{array}{c}\text { Staphylococcus aureus } \\
\text { (OD at 542 nm) }\end{array}$ & $\begin{array}{c}\text { Bacillus subtilis } \\
\text { (OD at 542 nm) }\end{array}$ \\
\hline 0 & 0.295 & 0.371 & 0.386 \\
\hline 1 & 0.349 & 0.409 & 0.429 \\
\hline 2 & 0.371 & 0.436 & 0.461 \\
\hline 3 & 0.398 & 0.468 & 0.493 \\
\hline 4 & 0.406 & 0.482 & 0.508 \\
\hline 5 & 0.454 & 0.501 & 0.514 \\
\hline 6 & 0.487 & 0.524 & 0.552 \\
\hline 7 & 0.501 & 0.547 & 0.586 \\
\hline
\end{tabular}

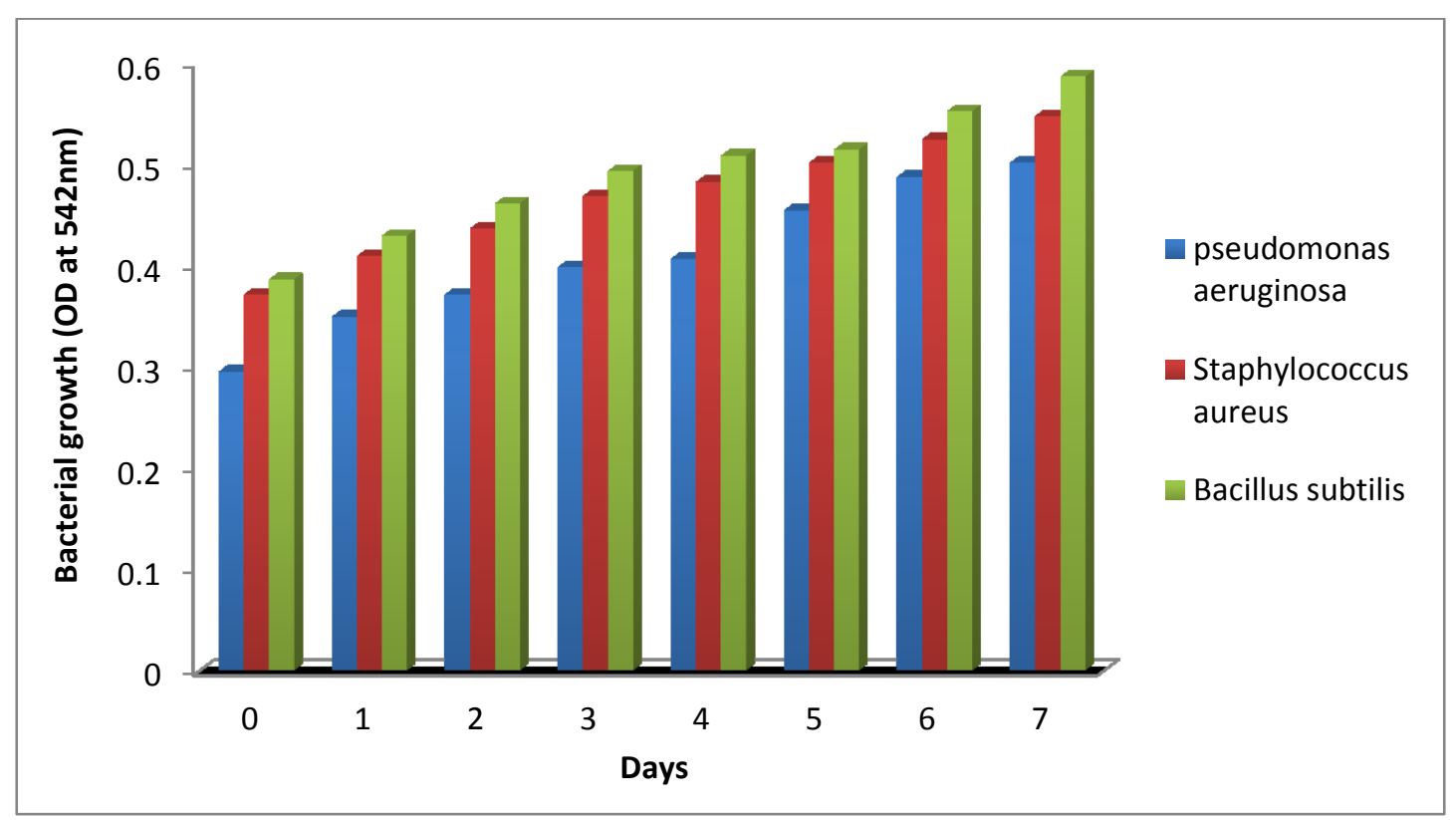

Fig. 2. Clustered column chart of Growth of pesticide degrading bacterial isolates on Minimal Salt broth containing Profenofos.

Microorganisms are involved in soil processes such as recycling of essential plant nutrients, humus formation and soil structure stability. The addition of pesticides may disturb the equilibrium and thus fertility of the soil. The chances of isolating microbial strains from polluted soils, with high ability to metabolize a particular xenobiotic are brighter [6]. During enrichment with a xenobiotic compound, the natural selection of microorganisms which have been adapted to the presence of that xenobiotic and its rapid biodegradation are known to take place [7]. Recently, Murugesan et al. [8] studied the ability of five bacterial isolates (Pseudomonas aeruginosa, Bacillus subtilis, Escherichia coli and Corynebacterium) to degrade cypermethrin. It was confirmed that these isolated organisms were able to utilize and degrade cypermethrin. On that five different bacterial colonies, Pseudomonas aeruginosa, Bacillus subtilis, Escherichia coli were found active in utilizing cypermethrin (1\%) where as 
Bacillus subtilis and Corynebacterium were moderately active in utilizing cypermethrin $(0.1$ $\%$ ). The growth curve experiment was performed at 0.1 and $1 \%$ dose of cypermethrin to analyze the viable count of Pseudomonas aeruginosa.

In this research, the growth of the three pesticides degrading isolates Pseudomonas aeruginosa, Staphylococcus aureus and Bacillus subtilis was assessed in Minimal salt broth containing $25 \mathrm{ppm}$ of pesticides at different temperature levels $25^{\circ} \mathrm{C}, 30^{\circ} \mathrm{C}, 35^{\circ} \mathrm{C}, 40{ }^{\circ} \mathrm{C}, 45$ ${ }^{\circ} \mathrm{C}, 50^{\circ} \mathrm{C}$ and $55^{\circ} \mathrm{C}$. Two different pesticides Metribuzin and Profenofos were used in this study. The maximum growth rate of bacteria was recorded at $35{ }^{\circ} \mathrm{C}$ followed by $30{ }^{\circ} \mathrm{C}, 25$ ${ }^{\circ} \mathrm{C}, 40{ }^{\circ} \mathrm{C}, 45^{\circ} \mathrm{C}$ and $50{ }^{\circ} \mathrm{C}$. The least growth rate was recorded at $55^{\circ} \mathrm{C}$. Among the three bacterial isolates, the bacteria Bacillus subtilis utilized the pesticides effectively and showed (Table and Fig. 3 \& Fig. 4) maximum growth followed by Pseudomonas aeruginosa and Staphylococcus aureus. The bacterial isolates showed maximum growth in the Minimal salt broth containing Profenofos (0.789) followed by Metribuzin (0.675).

Table 3. Effect of temperature for the growth of pesticide degrading bacteria in Minimal Salt broth containing Metribuzin.

\begin{tabular}{|c|c|c|c|}
\hline Temperature ${ }^{\circ} \mathrm{C}$ & $\begin{array}{c}\text { Pseudomonas aeruginosa } \\
\text { (OD at 542nm) }\end{array}$ & $\begin{array}{c}\text { Staphylococcus aureus } \\
\text { (OD at 542 nm) }\end{array}$ & $\begin{array}{c}\text { Bacillus subtilis } \\
\text { (OD at 542 nm) }\end{array}$ \\
\hline 25 & 0.493 & 0.581 & 0.626 \\
\hline 30 & 0.528 & 0.615 & 0.643 \\
\hline 35 & 0.597 & 0.652 & 0.675 \\
\hline 40 & 0.504 & 0.549 & 0.584 \\
\hline 45 & 0.399 & 0.453 & 0.492 \\
\hline 50 & 0.361 & 0.407 & 0.469 \\
\hline 55 & 0.326 & 0.388 & 0.431 \\
\hline
\end{tabular}

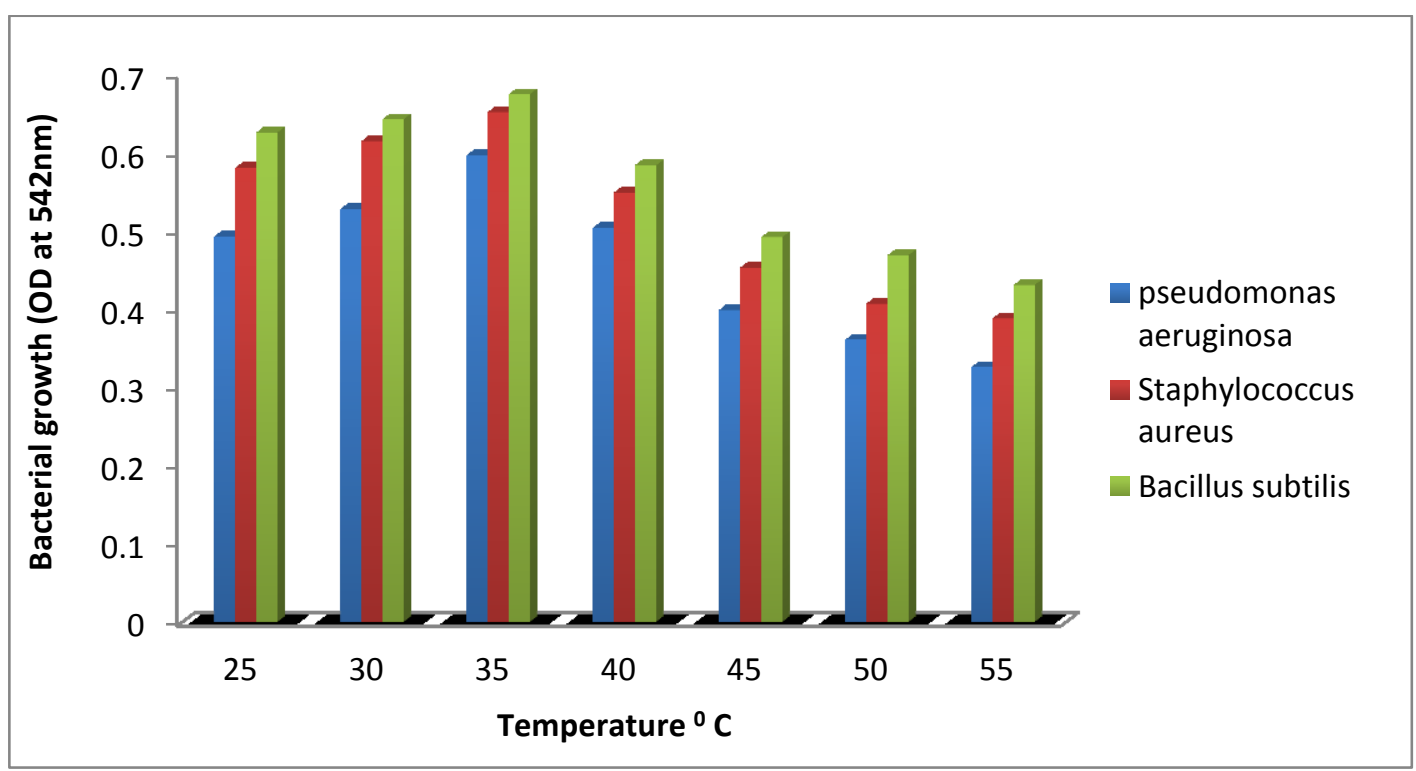

Fig. 3. Clustered column chart of temperature for the growth of pesticide degrading bacteria in Minimal Salt broth containing Metribuzin. 
Table 4. Effect of temperature for the growth of pesticide degrading bacteria in Minimal Salt broth containing Profenofos.

\begin{tabular}{|c|c|c|c|}
\hline Temperature ${ }^{\circ} \mathrm{C}$ & $\begin{array}{c}\text { Pseudomonas aeruginosa } \\
\text { (OD at 542 } \mathrm{nm} \text { ) }\end{array}$ & $\begin{array}{c}\text { Staphylococcus aureus } \\
\text { (OD at 542 } \mathrm{nm} \text { ) }\end{array}$ & $\begin{array}{c}\text { Bacillus subtilis } \\
\text { (OD at 542 nm) }\end{array}$ \\
\hline 25 & 0.587 & 0.714 & 0.736 \\
\hline 30 & 0.632 & 0.739 & 0.761 \\
\hline 35 & 0.706 & 0.765 & 0.789 \\
\hline 40 & 0.614 & 0.628 & 0.645 \\
\hline 45 & 0.522 & 0.593 & 0.607 \\
\hline 50 & 0.475 & 0.521 & 0.568 \\
\hline 55 & 0.428 & 0.497 & 0.526 \\
\hline
\end{tabular}

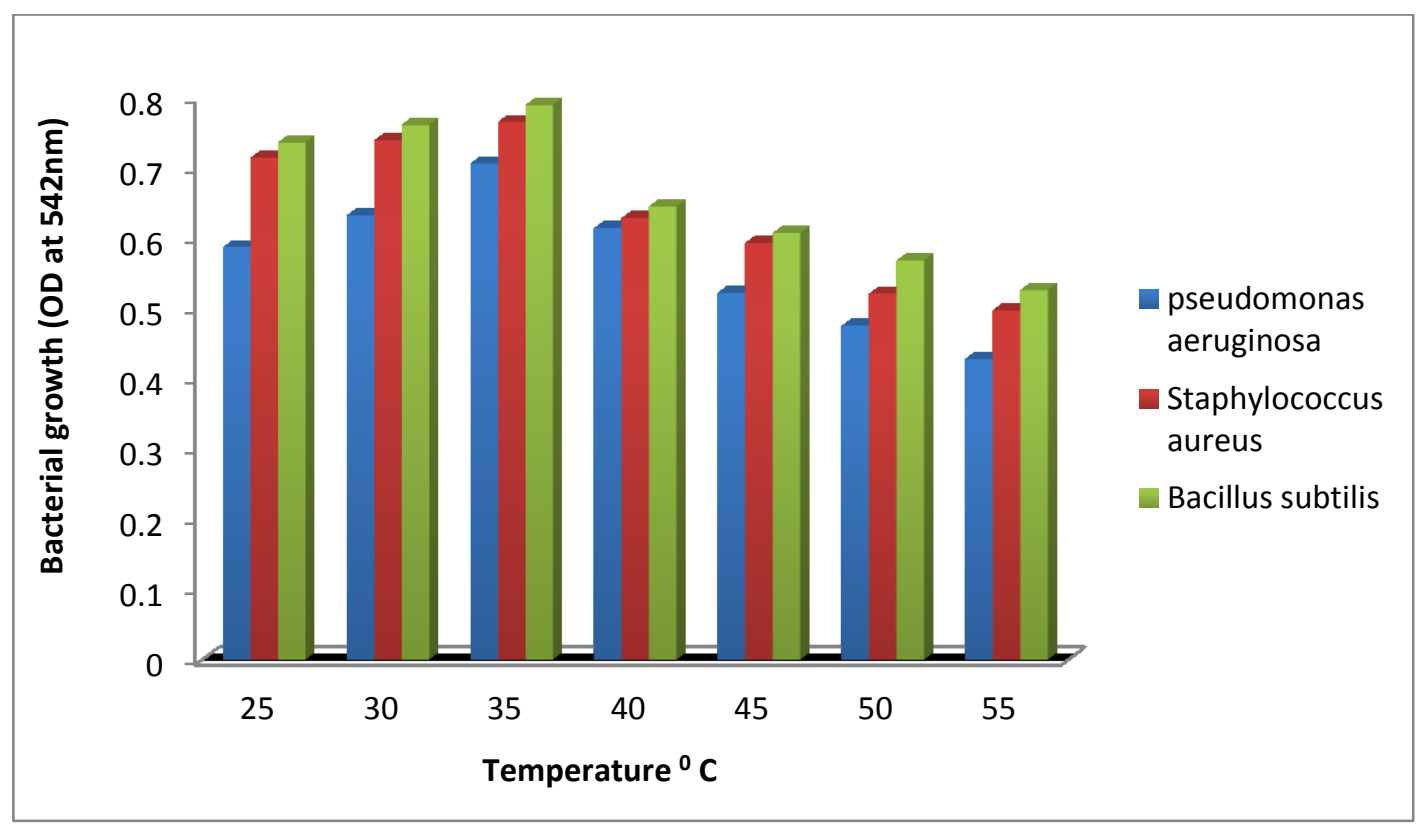

Fig. 4. Clustered column chart of temperature for the growth of pesticide degrading bacteria in Minimal Salt broth containing Profenofos.

The present study well with Perclich and Lockwood [9] observed that incidence of pesticide utilizing bacterial genera such as Bacillus, Micrococcus, Pseudomonas and Vibrio in the water and sediment samples of irrigational channel. Walker et al. [10] investigated that, Pesticide is mainly degraded by Pseudomonas and Bacillus and this versatility might be due to the presence of wide range of enzymes.

In this study, the growth of the three pesticides degrading isolates Pseudomonas aeruginosa, Staphylococcus aureus and Bacillus subtilis was assessed in Minimal salt broth containing $25 \mathrm{ppm}$ of pesticides at different $\mathrm{pH}$ levels $\mathrm{pH} 4, \mathrm{pH} \mathrm{5,pH} \mathrm{6,} \mathrm{pH} 7$ and $\mathrm{pH} 8$. Two different pesticides Metribuzin and Profenofos were used in this study. The maximum growth rate of bacteria was recorded at $\mathrm{pH} 6$ followed by $\mathrm{pH} 7, \mathrm{pH} 8$ and $\mathrm{pH} 5$. The least growth rate of Bacillus subtilis was recorded at $\mathrm{pH} 4$. Among the three bacterial isolates, the bacteria 
Bacillus subtilis utilized the pesticides effectively and showed maximum growth followed by Pseudomonas aeruginosa and Staphylococcus aureus. The bacterial isolates showed (Table and Fig. 5 \& Fig. 6) maximum growth in the Minimal salt broth containing Profenofos (0.781) followed by Metribuzin (0.669).

Table 5. Effect of $\mathrm{pH}$ for the growth of pesticide degrading bacteria in Minimal Salt broth containing Metribuzin.

\begin{tabular}{|c|c|c|c|}
\hline $\mathrm{pH}$ & $\begin{array}{c}\text { Pseudomonas aeruginosa } \\
\text { (OD at 542 } \mathrm{nm} \text { ) }\end{array}$ & $\begin{array}{c}\text { Staphylococcus aureus } \\
\text { (OD at 542 } \mathrm{nm} \text { ) }\end{array}$ & $\begin{array}{c}\text { Bacillus subtilis } \\
\text { (OD at 542 nm) }\end{array}$ \\
\hline 4 & 0.376 & 0.442 & 0.497 \\
\hline 5 & 0.532 & 0.568 & 0.611 \\
\hline 6 & 0.581 & 0.594 & 0.669 \\
\hline 7 & 0.559 & 0.586 & 0.538 \\
\hline 8 & 0.543 & 0.572 & 0.524 \\
\hline
\end{tabular}

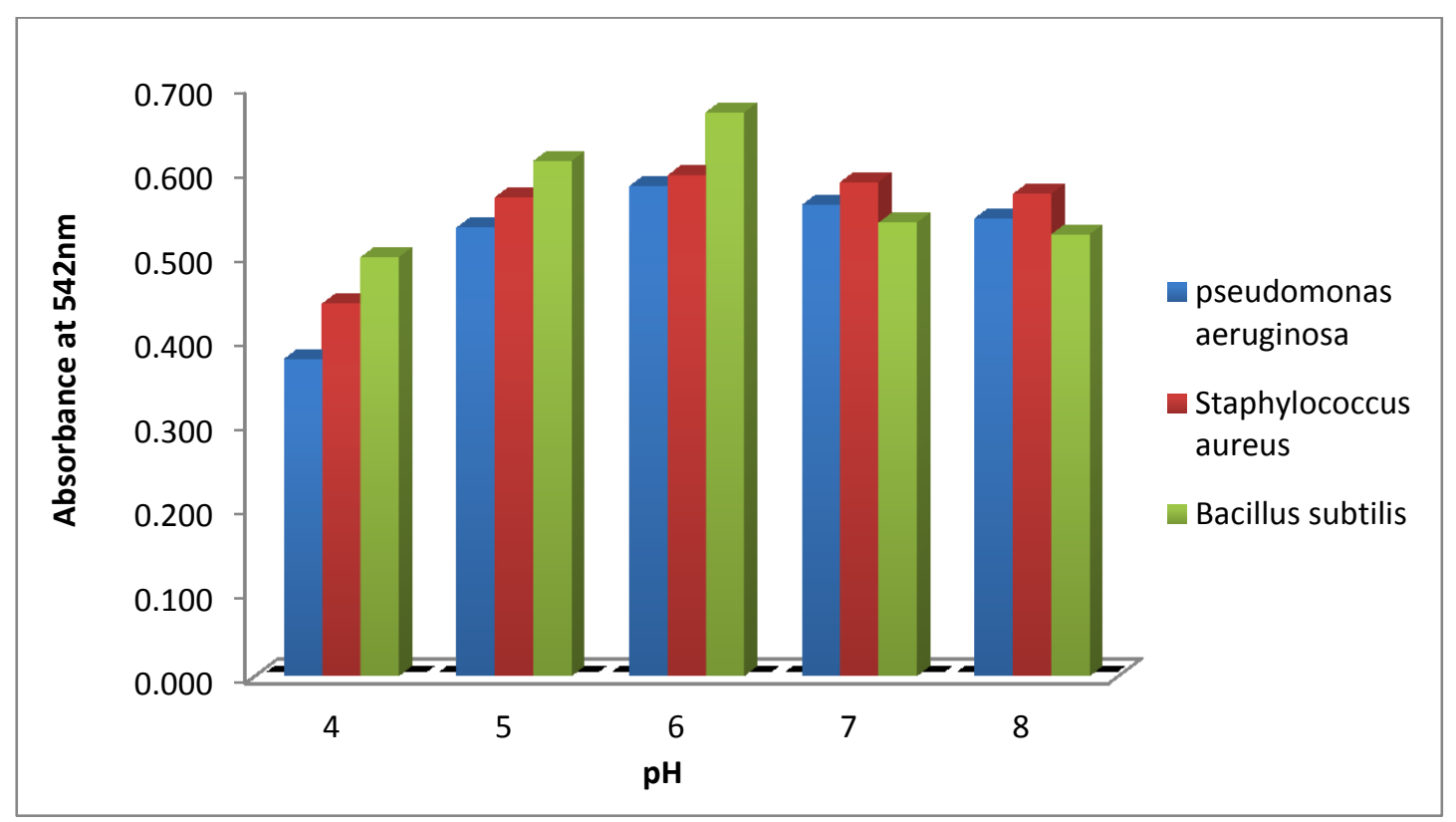

Fig. 5. Clustered column chart of $\mathrm{pH}$ for the growth of pesticide degrading bacteria in Minimal Salt broth containing Metribuzin.

Enhanced degradation of Profenofos by Enterobacter strain was reported by [11]. Yang et al. [12] isolated Alkaligenes faecalis, which is capable of degrading Profenofos and 3, 5, 6-trichloro-2-pyridinol (TCP). Six Profenofos-degrading bacteria were isolated using Profenofos as the sole carbon source by an enrichment procedure [13]. 
Table 6. Effect of $\mathrm{pH}$ for the growth of pesticide degrading bacteria in Minimal Salt broth containing Profenofos.

\begin{tabular}{|c|c|c|c|}
\hline $\mathrm{pH}$ & $\begin{array}{c}\text { Pseudomonas aeruginosa } \\
\text { (OD at 542 } \mathrm{nm})\end{array}$ & $\begin{array}{c}\text { Staphylococcus aureus } \\
\text { (OD at 542 nm) }\end{array}$ & $\begin{array}{c}\text { Bacillus subtilis } \\
\text { (OD at 542 nm) }\end{array}$ \\
\hline 4 & 0.481 & 0.558 & 0.593 \\
\hline 5 & 0.626 & 0.685 & 0.725 \\
\hline 6 & 0.769 & 0.723 & 0.781 \\
\hline 7 & 0.694 & 0.689 & 0.764 \\
\hline 8 & 0.652 & 0.647 & 0.752 \\
\hline
\end{tabular}

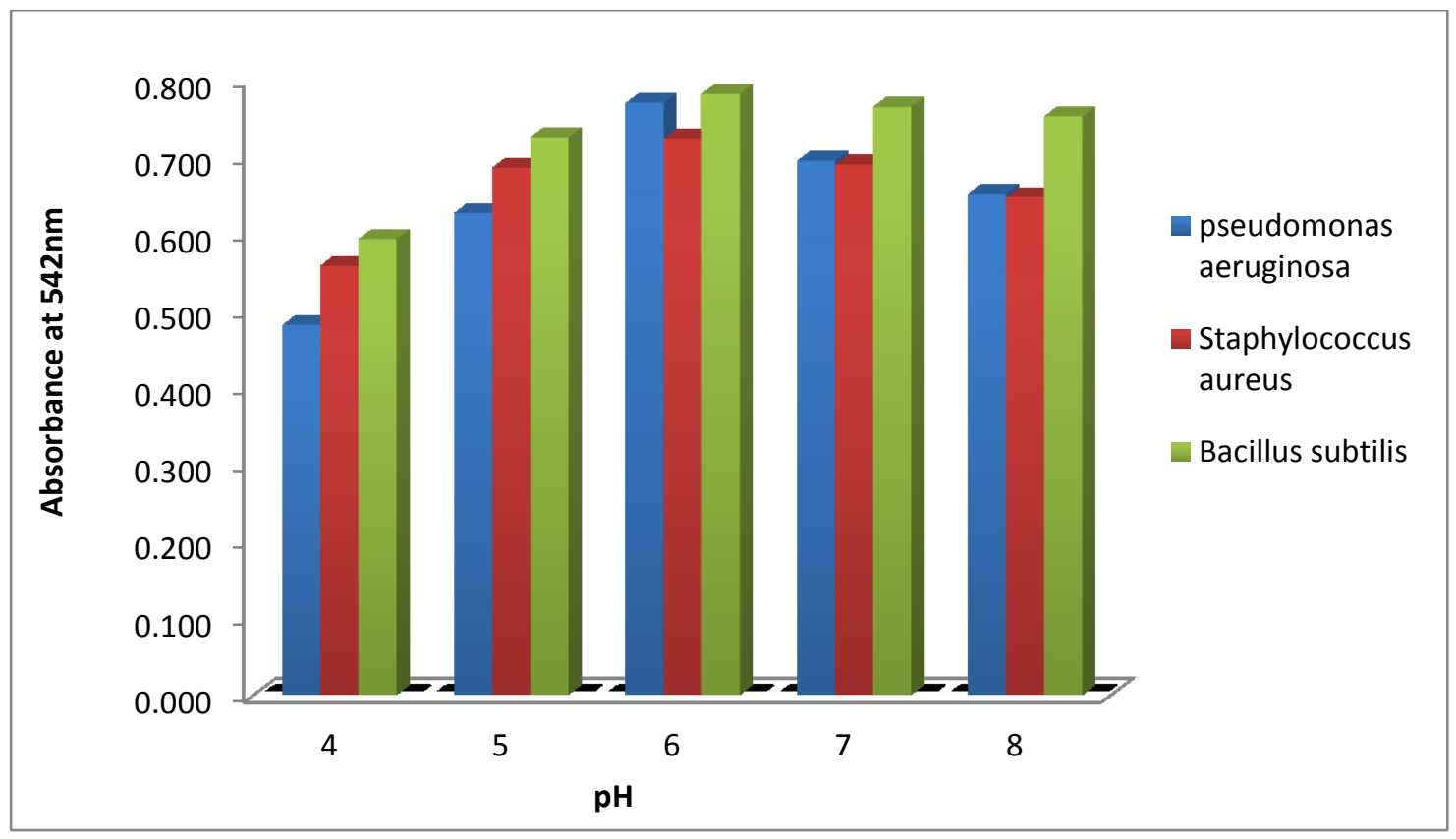

Fig. 6. Clustered column chart of $\mathrm{pH}$ for the growth of pesticide degrading bacteria in Minimal Salt broth containing Profenofos.

Choi et al. [14] isolated three parathion-degrading bacteria and eight pairs of bacteria showing syntrophic metabolism of parathion from rice field soils, and investigated their genetic and phenotypic characteristics. The three isolates and eight syntrophic pairs were able to utilize parathion as a sole source of carbon and energy, producing p-nitrophenol as the intermediate metabolite during the complete degradation of parathion.

In the present study, the growth of the three pesticides degrading isolates Pseudomonas aeruginosa, Staphylococcus aureus and Bacillus subtilis was assessed in Minimal salt broth containing $25 \mathrm{ppm}$ of pesticides using different carbon sources Lactose, Dextrose, Fructose, Mannose and Galactose. Two different pesticides Metribuzin and Profenofos were used in this study. The maximum growth of bacteria was in the presence of Dextrose followed by Fructose, Galactose and Mannose. 
The least growth was recorded in Lactose. Among the three bacterial isolates, the bacteria Bacillus subtilis utilized the pesticides effectively and showed maximum growth followed by Staphylococcus aureus and Pseudomonas aeruginosa. The bacterial isolates showed (Tabe and Fig. 7 \& Fig. 8) maximum growth in the Minimal salt broth containing Profenofos (0.784) followed by Metribuzin (0.686).

Table 7. Effect of carbon sources for the growth of pesticide degrading bacteria in Minimal Salt broth containing Metribuzin.

\begin{tabular}{|c|c|c|c|}
\hline $\begin{array}{l}\text { Carbon } \\
\text { source }\end{array}$ & $\begin{array}{c}\text { Pseudomonas aeruginosa } \\
\text { (OD at 542 nm) }\end{array}$ & $\begin{array}{c}\text { Staphylococcus aureus } \\
\text { (OD at 542 nm) }\end{array}$ & $\begin{array}{c}\text { Bacillus subtilis } \\
\text { (OD at 542 nm) }\end{array}$ \\
\hline lactose & 0.491 & 0.522 & 0.596 \\
\hline Dextrose & 0.624 & 0.647 & 0.686 \\
\hline Fructose & 0.548 & 0.603 & 0.668 \\
\hline Mannose & 0.511 & 0.588 & 0.562 \\
\hline Galactose & 0.569 & 0.601 & 0.573 \\
\hline
\end{tabular}

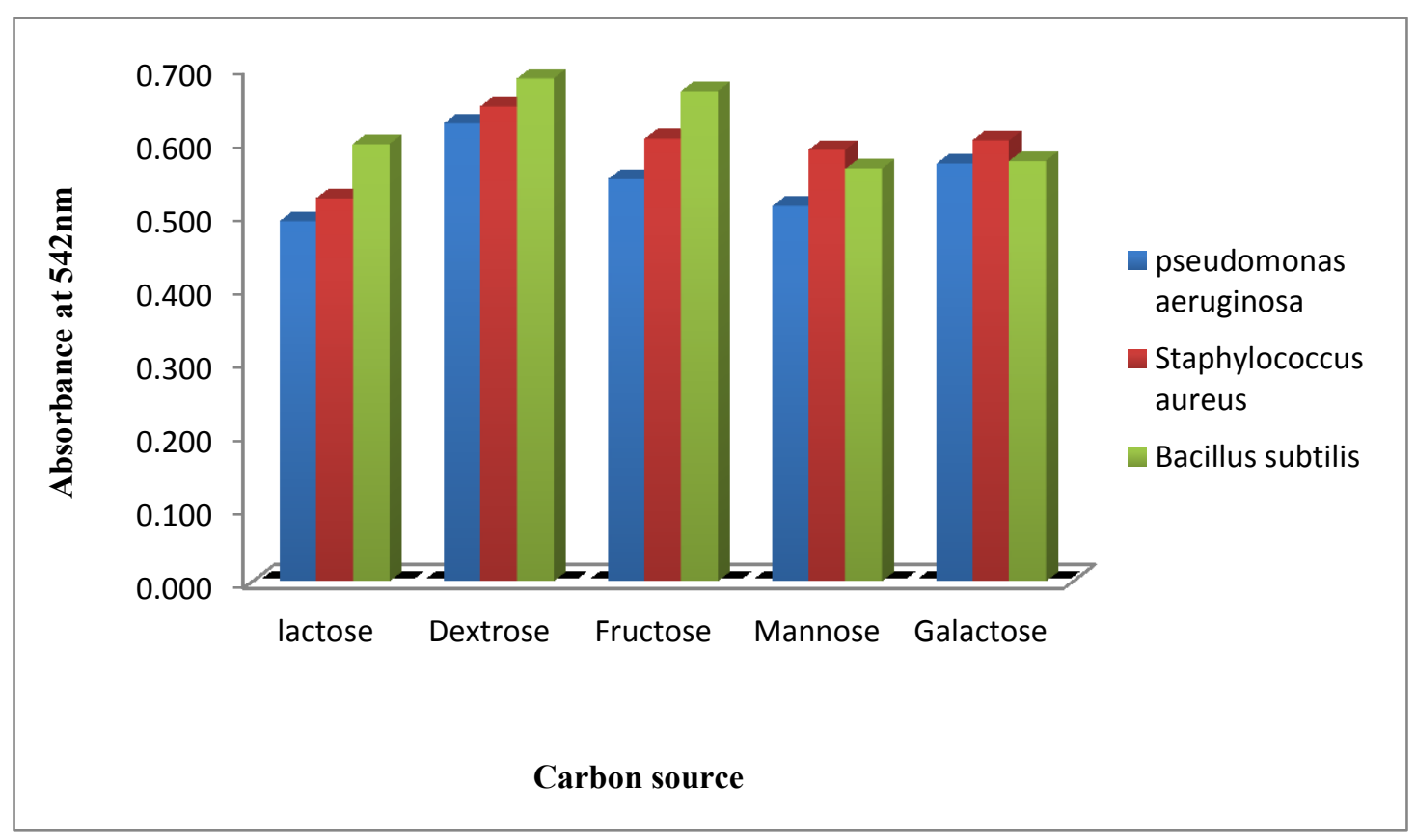

Fig. 7. Clustered column chart of carbon sources for the growth of pesticide degrading bacteria in Minimal Salt broth containing Metribuzin. 
Table 8. Effect of carbon sources for the growth of pesticide degrading bacteria in Minimal Salt broth containing Profenofos.

\begin{tabular}{|c|c|c|c|}
\hline Carbon source & $\begin{array}{c}\text { Pseudomonas aeruginosa } \\
\text { (OD at 542 nm) }\end{array}$ & $\begin{array}{c}\text { Staphylococcus aureus } \\
\text { (OD at 542 nm) }\end{array}$ & $\begin{array}{c}\text { Bacillus subtilis } \\
\text { (OD at 542 nm) }\end{array}$ \\
\hline lactose & 0.597 & 0.644 & 0.699 \\
\hline Dextrose & 0.723 & 0.756 & 0.784 \\
\hline Fructose & 0.669 & 0.723 & 0.765 \\
\hline Mannose & 0.635 & 0.704 & 0.701 \\
\hline Galactose & 0.681 & 0.716 & 0.738 \\
\hline
\end{tabular}

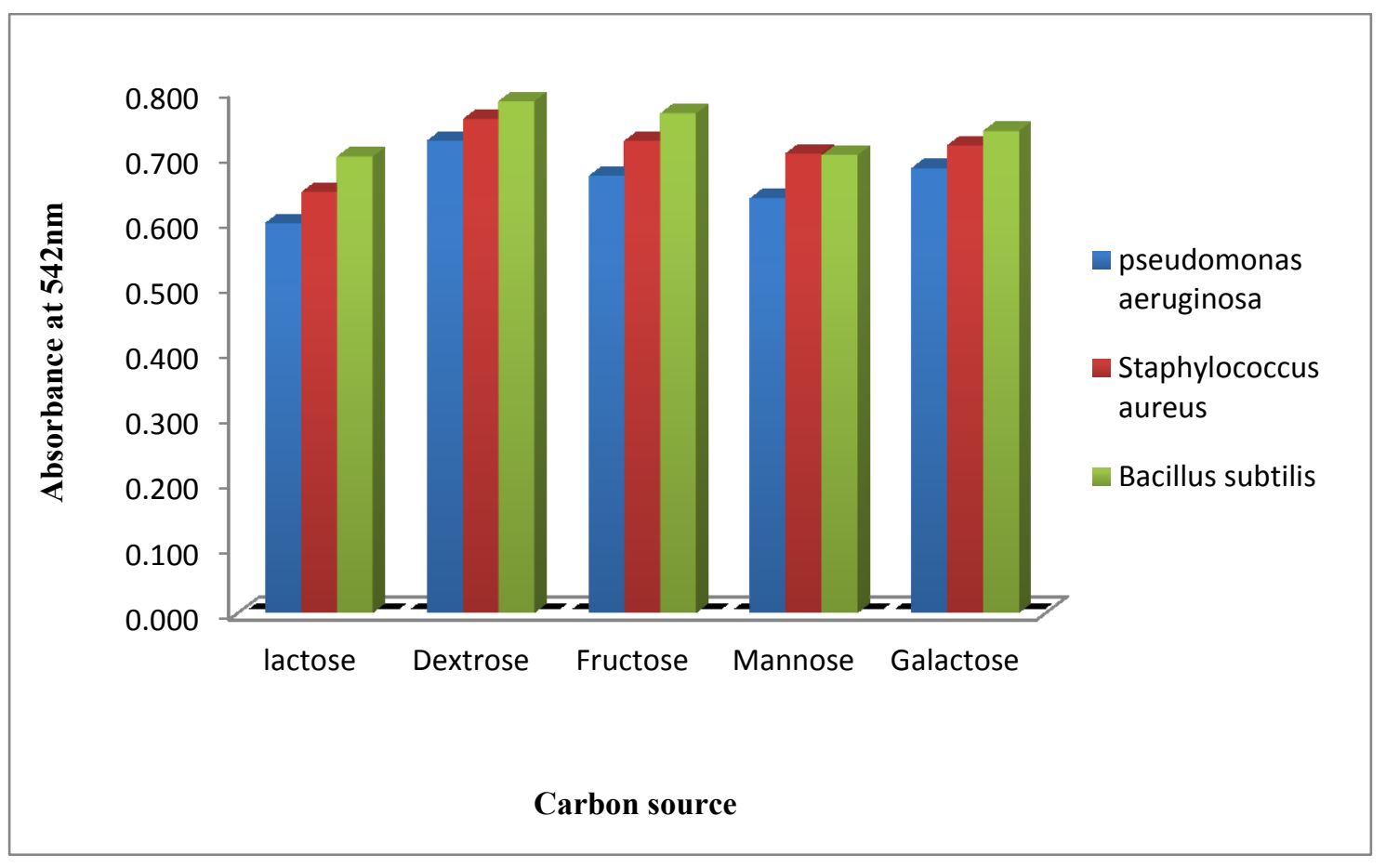

Fig. 8. Clustered column chart of carbon sources for the growth of pesticide degrading bacteria in Minimal Salt broth containing Profenofos.

In this present research, the growth of the three pesticide degrading isolates Pseudomonas aeruginosa, Staphylococcus aureus and Bacillus subtilis was assessed in minimal salt broth containing $25 \mathrm{ppm}$ of pesticides using different nitrogen sources Peptone, Yeast extract, Beef extract, Malt extract and Casein. Two different pesticides Metribuzin and Profenofos were used in this study.

The maximum growth of bacteria was in the presence of Malt extract followed by Peptone, Yeast extract and Casein. The least growth was recorded in Beef extract. Among the three bacterial isolates, the bacteria Bacillus subtilis utilized the pesticides effectively and showed maximum growth followed by Staphylococcus aureus and Pseudomonas aeruginosa. 
The bacterial isolates showed (Table and Fig. 9 \& Fig. 10) maximum growth in the Minimal salt broth containing Profenofos (0.771) followed by Metribuzin (0.644).

The result of the study well confirmed by Murugesan et al. [8] studied the ability of four bacterial isolates (Pseudomonas aeruginosa, Bacillus subtilis, Escherichia coli and Corynebacterium) to degrade cypermethrin.

It was confirmed that these isolated organisms were able to utilize and degrade cypermethrin.

Table 9. Effect of nitrogen sources for the growth of pesticide degrading bacteria in Minimal Salt broth containing Metribuzin.

\begin{tabular}{|c|c|c|c|}
\hline Nitrogen source & $\begin{array}{c}\text { Pseudomonas aeruginosa } \\
\text { (OD at 542 nm) }\end{array}$ & $\begin{array}{c}\text { Staphylococcus aureus } \\
\text { (OD at 542 nm) }\end{array}$ & $\begin{array}{c}\text { Bacillus subtilis } \\
\text { (OD at 542 nm) }\end{array}$ \\
\hline Peptone & 0.538 & 0.591 & 0.632 \\
\hline Yeast extract & 0.502 & 0.566 & 0.603 \\
\hline Beef extract & 0.485 & 0.531 & 0.578 \\
\hline Malt extract & 0.547 & 0.595 & 0.644 \\
\hline casein & 0.498 & 0.553 & 0.589 \\
\hline
\end{tabular}

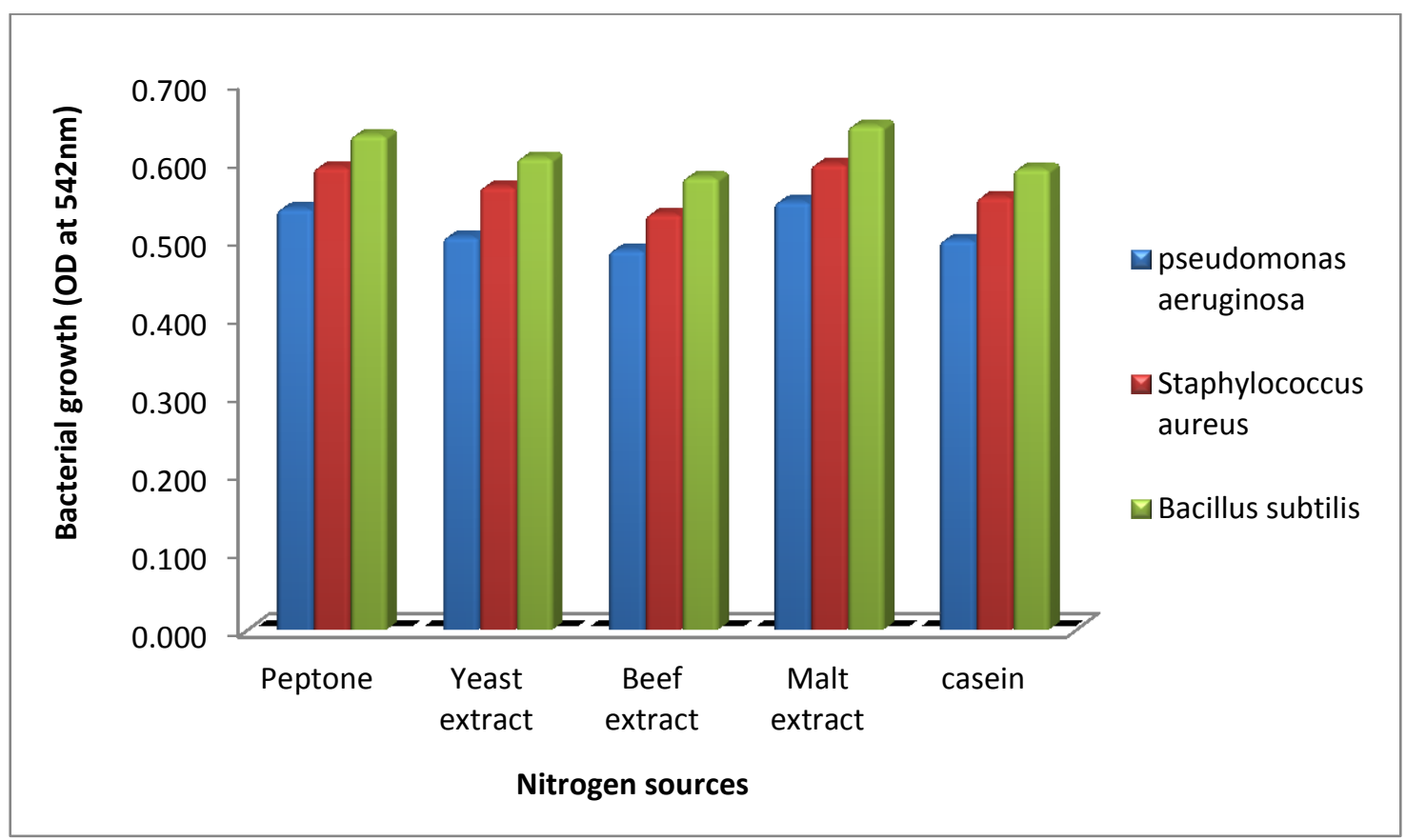

Fig. 9. Clustered column chart of nitrogen sources for the growth of pesticide degrading bacteria in Minimal Salt broth containing Metribuzin. 
Table 10. Effect of nitrogen sources for the growth of pesticide degrading bacteria in Minimal Salt broth containing Profenofos.

\begin{tabular}{|c|c|c|c|}
\hline Nitrogen source & $\begin{array}{c}\text { Pseudomonas aeruginosa } \\
\text { (OD at 542 } \mathrm{nm} \text { ) }\end{array}$ & $\begin{array}{c}\text { Staphylococcus aureus } \\
\text { (OD at 542 nm) }\end{array}$ & $\begin{array}{c}\text { Bacillus subtilis } \\
\text { (OD at 542 nm) }\end{array}$ \\
\hline Peptone & 0.642 & 0.686 & 0.757 \\
\hline Yeast extract & 0.618 & 0.671 & 0.714 \\
\hline Beef extract & 0.597 & 0.643 & 0.681 \\
\hline Malt extract & 0.656 & 0.695 & 0.771 \\
\hline casein & 0.593 & 0.661 & 0.690 \\
\hline
\end{tabular}

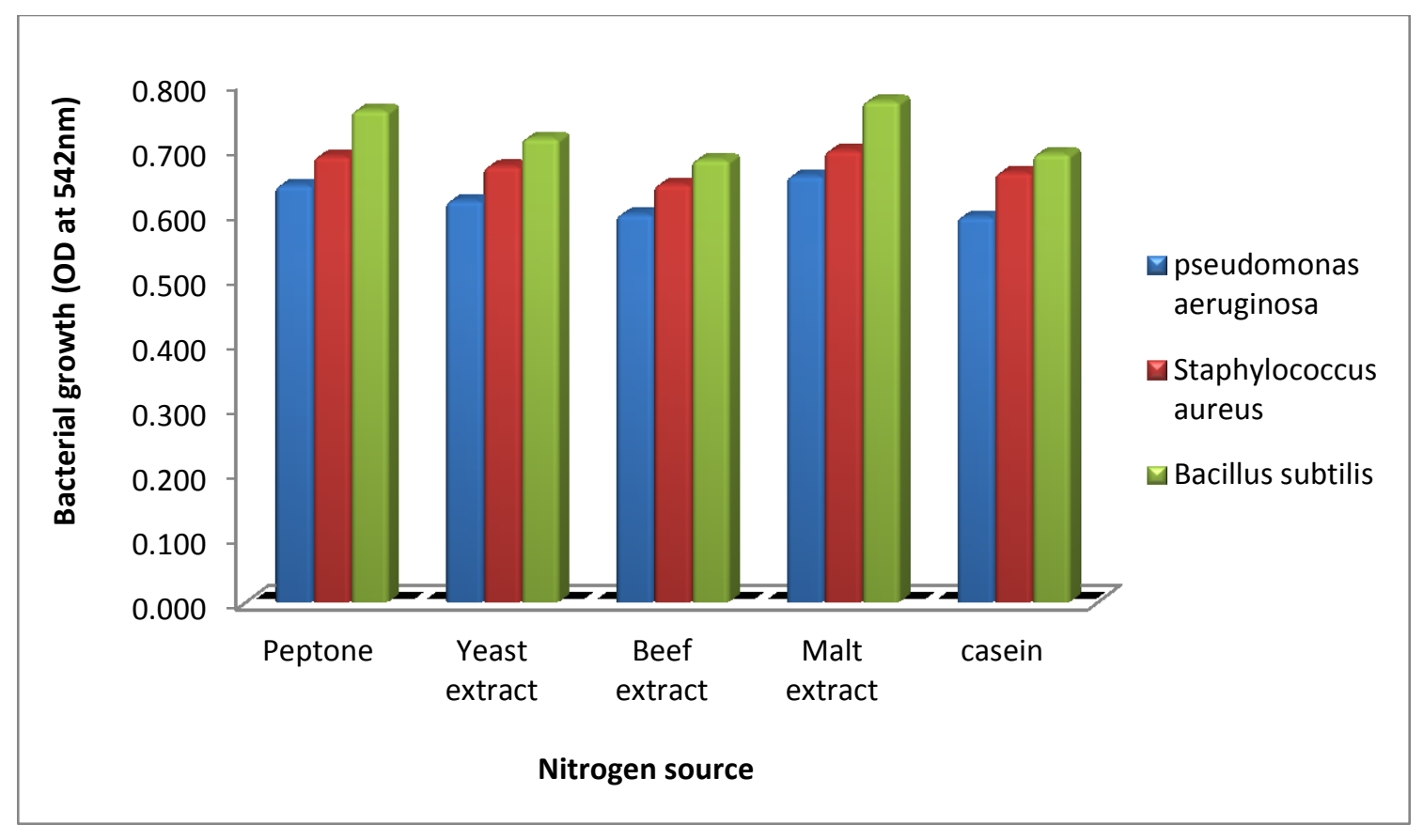

Fig. 10. Clustered column chart of nitrogen sources for the growth of pesticide degrading bacteria in Minimal Salt broth containing Profenofos.

\section{CONCLUSIONS}

From this study, it was concluded that the bacterial isolates like Pseudomonas aeruginosa, Staphylococcus aureus and Bacillus subtilis have the capacity to utilize the pesticides and grow well in the medium supplemented with pesticides as a carbon source. Among the isolated bacteria Bacillus subtilis grows well in the presence of pesticides 
followed by Staphylococcus aureus and Pseudomonas aeruginosa. The isolates Pseudomonas aeruginosa and Staphylococcus aureus also have the capacity to control many diseases. These bacterial isolates have the capacity to utilize the pesticides as a nutrient and also degrade very fast in the culture broth. It is concluded that both pesticide are biological degradable. Thus use of the both bacterial isolates in the biological treatment of pesticide contaminated soil will give fruitful results. Replacement of chemical pesticides with biopesticides like Pseudomonas aeruginosa and Staphylococcus aureus will minimize the pesticide contamination in agricultural soil.

\section{References}

[1] Ramanathan M. P., D. Lalithakumari, Appl. Biochem. Biotechnol. 80 (1999) 1-12.

[2] Shen L., F. Wania Y., D. Lei, C. Teixeira, D. C. Muir, T. C. Bidleman, Environmental Science and Technology 15 (2005) 409-420.

[3] Yanez L., D. Ortiz-perez L. E. Batres, L. Borja-aburto, F. Diaz-barriga, Environmental Research Section 88 (2002) 174-181.

[4] Bould H. L., New Zealand Journal of Agricultural Research 38 (1994) 257-277.

[5] EPA. 2000. Http://www.epa.gov/reds/factsheets/p155fct.pdf.

[6] Feng Y., K. D. Racke, J. M. Bollag, Applied Environmental Microbiology 63 (1997) 4096-4098.

[7] Cullington J. E., A. Walker, Soil Biology and Biochemistry 31 (1999) 677-686.

[8] Murugesan A. G., T. Jeyasanthi, S. Maheswari, African Journal of Microbiology Research 4(1) (2010) 10-13.

[9] Perclich J. A., J. L. Lockwood, Can. J. Mirobiol. 24 (1978) 1145-1152.

[10] Walker A., N. R. Perekh, S. J. Roberts, S. J. Welch, Pestic. Sci. 39 (1993) 55-60.

[11] Singh B. K., A. Walker, J. A. Morgan, D. J. Wright, Appl. Environ. Microbiol. 70 (2004) 4855-4863.

[12] Yang L., Y. H. Zhao, B. X. Zhang, C. H. Yang, X. Zhang, Femsmicrobiol. Lett. 251 (2005) 67-73.

[13] Yang C., N. Liu, X. Guo, C. Qiao, Femsmicrobiol. Lett. 265 (2006) 118-125.

[14] Choi Min-Kyeong, Kyung-Duk Kim, Kyong-Mok Ahn, Dong-Hyun Shin, Jae-Hong Hwang, Chi Nam Seong, Jong-Ok Ka, J. Microbiol. Biotechnol. 19(12) (2009) 16791687. 